\title{
Characterization of Historic Binders and Stones of a Ruined Medieval Church (Hungary)
}

\author{
Zsuzsanna Kósa1, Ákos Török ${ }^{1 *}$ \\ ${ }^{1}$ Department of Engineering Geology and Geotechnics, Faculty of Civil Engineering, Budapest University of Technology and \\ Economics, H-1111 Budapest, Múegyetem rkp. 3., Hungary \\ * Corresponding author, e-mail: torokakos@mail.bme.hu
}

Received: 20 January 2020, Accepted: 04 March 2020, Published online: 22 April 2020

\begin{abstract}
Construction materials of a partly ruined Medieval church of Central Hungary were studied in details to assess its conditions and to obtain information on the phases of construction. At first, digital images were taken to create a 3D model of the remaining walls. The material properties were measured in situ using non-destructive test methods. Strength parameters of stone and render were assessed by Schmidt hammer, while moisture content was measured by a portable moisture meter. According to lithological descriptions and thin-section analyses limestone prevail in the monument. The most common Miocene limestone is represented by various lithologies, such as cemented macro porous limestone, fine-grained porous limestone, oolitic limestone and bioclastic limestone. Mesozoic micritic well cemented limestone and Tertiary limonitic sandstone were also identified at the ruins. The most common weathering forms are selective dissolution, multiple flaking and biological colonisation. Renders used in the structure represents the long history of the structure from Medieval lime-based mortars to Portland cement containing latest applications. The former one is composed of quartz send in lime binder. According to Schmidt hammer tests, the rebound values of the replacement stone is higher than that of the original porous limestone. There is a distinct difference in the moisture content of the stone and render. Orientation/exposure of the wall also influences the moisture content. The gathered information allows for designing better repair methods and helps in the planning of the maintenance of the medieval stone heritage.
\end{abstract}

Keywords

medieval masonry, lime mortars, non-destructive test, microscopy

\section{Introduction}

In order to understand the processes of deterioration of medieval masonry walls, it is important to study the composition, and use of its mortar [1], plaster and stone and these building materials often contain a significant amount of archaeological information and reveal the history of reconstruction techniques [2]. Furthermore, the structural behaviour of stones [3] and renders [4], the construction history and the micro-environmental conditions also influence the preservation of these construction materials.

Choosing an incompatible repair material can result not only in the failure of the repair [5] but also the accelerated deterioration of the adjacent materials $[6,7,8]$.

Medieval architectural heritage structures are rare in Central Europe, and most of them are in ruins. Our study aimed to conduct an integrated investigation of the remnant masonry of an abandoned medieval church: masonry units (stones), mortar, the microstructure of the mortar, its composition, and an overview of physical and mechanical properties.

\section{History and conditions of ruins}

Most early medieval church of Hungary was built in the centuries of Arpad dynasty (972-1301) and some of them had been demolished during the centuries. The study site is a ruined medieval church near the village of Tök, in Pest country (Hungary) (Fig. 1). Samples were collected there and in-situ test were made on the ruined walls.

The church of Tök village was constructed most probably during the second half of the 13th century in Romanesque style [9]. The village churches from the Romanesque period are mostly small constructions consisting of two parts, the rectangular nave and the half-circle shape sanctuary. This 


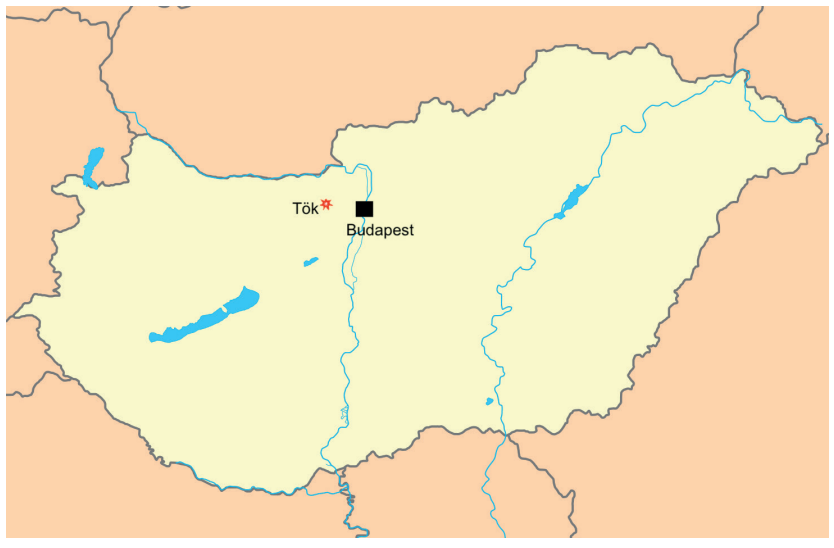

Fig. 1 Map of Hungary with the location of Tök

structure can be observed in the old church of Tök, too. The structure has a simple ground plan. The church is positioned symmetrically along the longitudinal axis, oriented to the east. At the east, the end of the nave is connected a round apse directly with higher floor level (Fig. 2).

Remaining parts of altars were installed into the north and south side-walls. The internal size of the nave is about $9.5 \mathrm{~m}$ long and $6.1 \mathrm{~m}$ wide and the semi-circular apse has about $2.3 \mathrm{~m}$ times $3.3 \mathrm{~m}$ dimension. The rectangular parts of the ruin have a length of $14 \mathrm{~m}$ and a width of $8.5 \mathrm{~m}$.

The degradation of the church was connected to the depopulation of municipally, which has many possible explanations according to Hungarian historians. One possibility is that the Tatars or later the Turks invaded that part of Hungary and the village was abandoned or moved a different place. Alternatively, it happened later, and it could have been after the Protestant Reformation [10, 11]. The masonry structure of the church than was degraded over time due to humidity and temperature fluctuations.
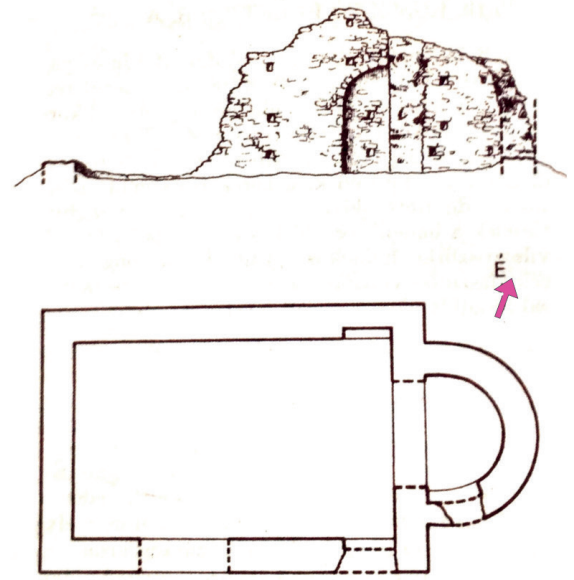

$s m$

Fig. 2 The ground plan and longitudinal section periodization in [10]
Cyclic exposures to humidity and frost as well as physical damage destroy the stone elements and mortar joints. The wood structures such as the roof or furniture have vanished over the centuries.

Some parts of the church were excavated by archaeologists; the foundations were explored, and also several masonry elements were found in 2000. Small sections of the walls were reconstructed with original elements or with replacements at that time [9].

The masonry of the church now shows signs of weathering and significant parts are missing (Fig. 3). Opposite to the sanctuary, the west oriented section of the walls is toppled almost down to the foundation. The other three sections are in better condition.

Although the western side of northern and the southern walls are almost levelled to the ground, the east-bound of these walls are higher and more robust, due to the reconstruction during 2000. The arch wall of the sanctuary was partly restored, and the southern wall inner part was also restored partly with a newly constructed altar according to the archaeological exploration. This did not hamper the the further deterioration of the walls, which still continues.

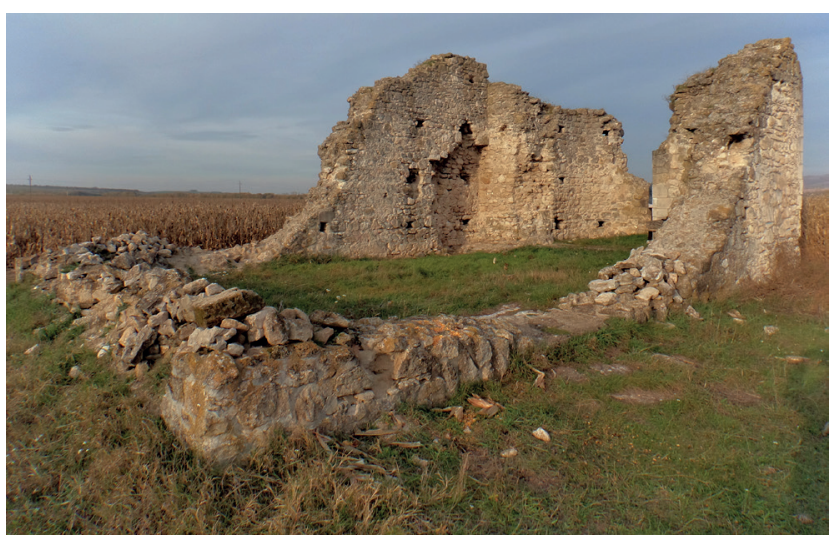

(a)

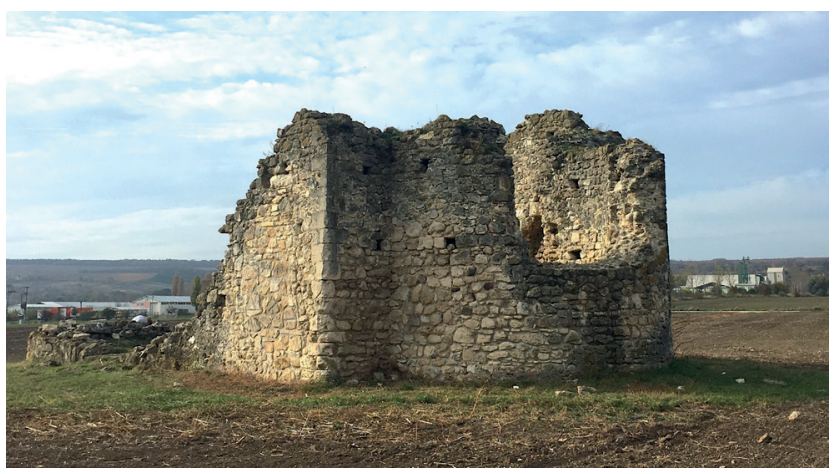

(b)

Fig. 3 The current condition of the ruined temple of Tök. (a) View from South showing the southern part of the apse. (b) View from Southwest 


\section{Photo-geometric model generation}

Images were taken from the ruin to create a $3 \mathrm{D}$ photorealistic model. The digital images were processed using AutoCAD Recap Photo software. The software allowed to create a model of the ruin that displays the details. After taking more than 200 site photos, the software creates textures and generates the model of the entire structure to represent the current conditions (Fig. 4).

\section{Building materials}

The major part of the building - more than $90 \%$ of masonry - is made of different types of limestones.

The limestone is mostly derived from local sources, but lithotypes of distant quarries were also identified; thus high variations in lithology of limestone were observed. The prevailing types of limestone belong to the Miocene so-called porous limestone sequence of the larger area [12].

The limestones show great variety in their textural characteristics and porosity. The identified lithotypes are: i) coarse-grained, ii) fine-grained, iii) medium-grained and shelly, iv) cemented, v) oolitic and vi) cross-layered,
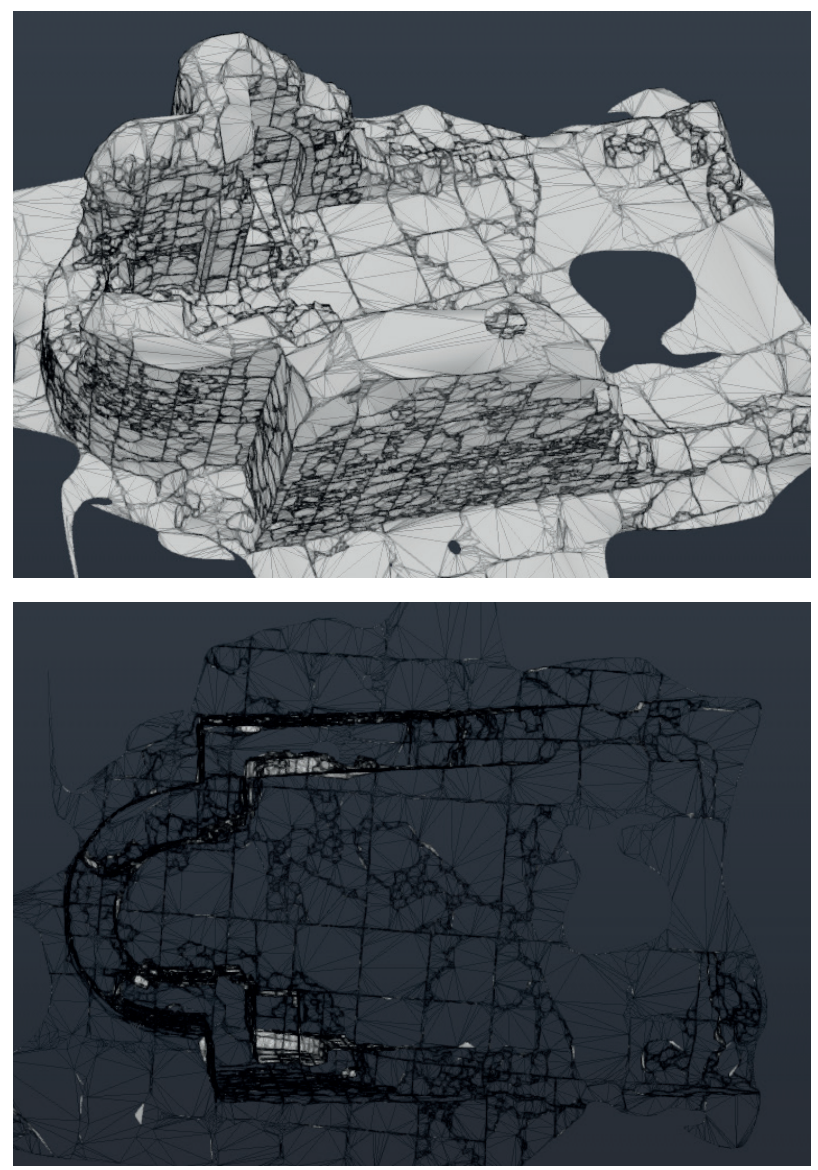

Fig. 4 The 3D geometric models of the ruin made with AutoCAD Recap Photo software based on 200 images limestone (Fig. 5). Some of these lithotypes are found at Sóskút area, and the oolitic variety is also the main construction material of Budapest [13]. Furthermore, in limited numbers, sandstone elements and sandy limestones were also discovered in the masonry. Variations in the characteristics of sedimentary rocks such as porosity, layering, the mineralogical composition can lead to differences in physical properties. These differences are evident when the differences in weathering forms and scales of weathering of masonry components are considered.

Visual inspection of historic mortars provides valuable information on their composition and origin. Tool marks, additives, as well as larger aggregate particles and type of binder, are often visible [14]. Two types of binder material were identified that were used for several types of mortars. Non-hydraulic lime binders - with a significant amount of non-hydrated white lime grains - were identified. These mortars contain different sizes of lime and sand grains, representing wide ranges and other additives. Additives of mortars are also visible in some samples; such as light pink stain and in other samples, black coloured fine sandsized grains and brick scraps (Fig. 6 and Table 1). These types of mortars are the most common ones in the historic
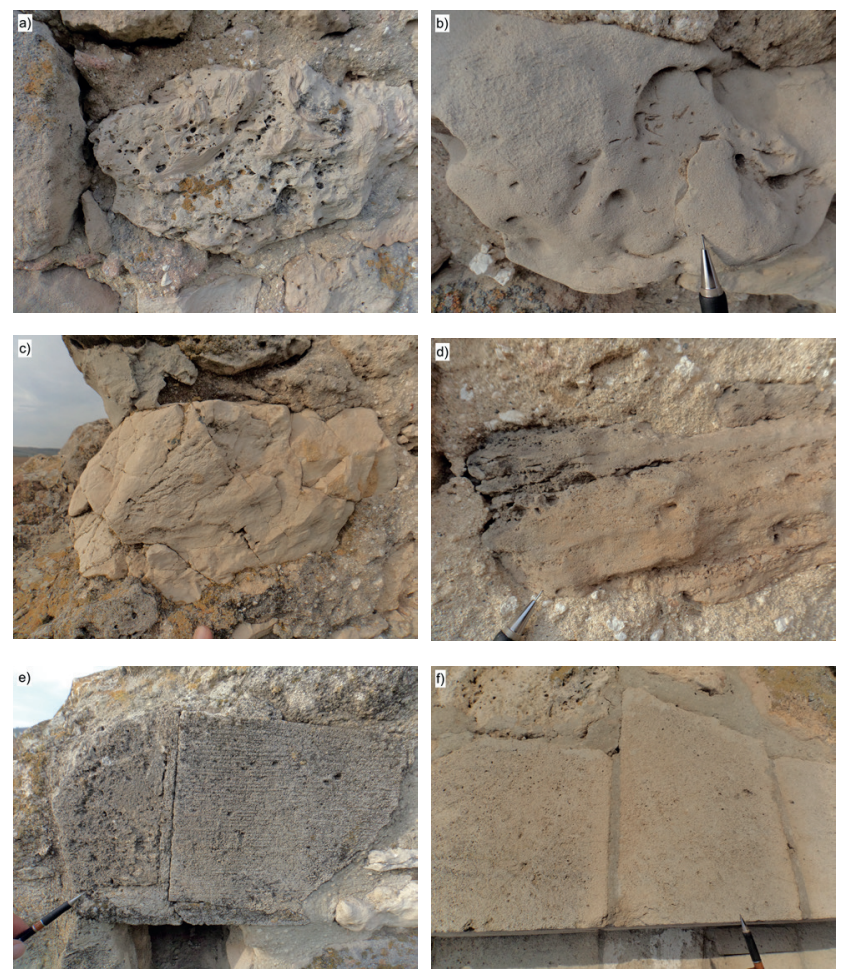

Fig. 5 Limestone masonry elements: (a) cemented macro-porous limestone; (b) sandy limestone; (c) highly cemented and cross layered limestone; (d) sandstone; (e) porous oolitic limestones (former replacement stone); (f) porous limestone (new replacement stone) 

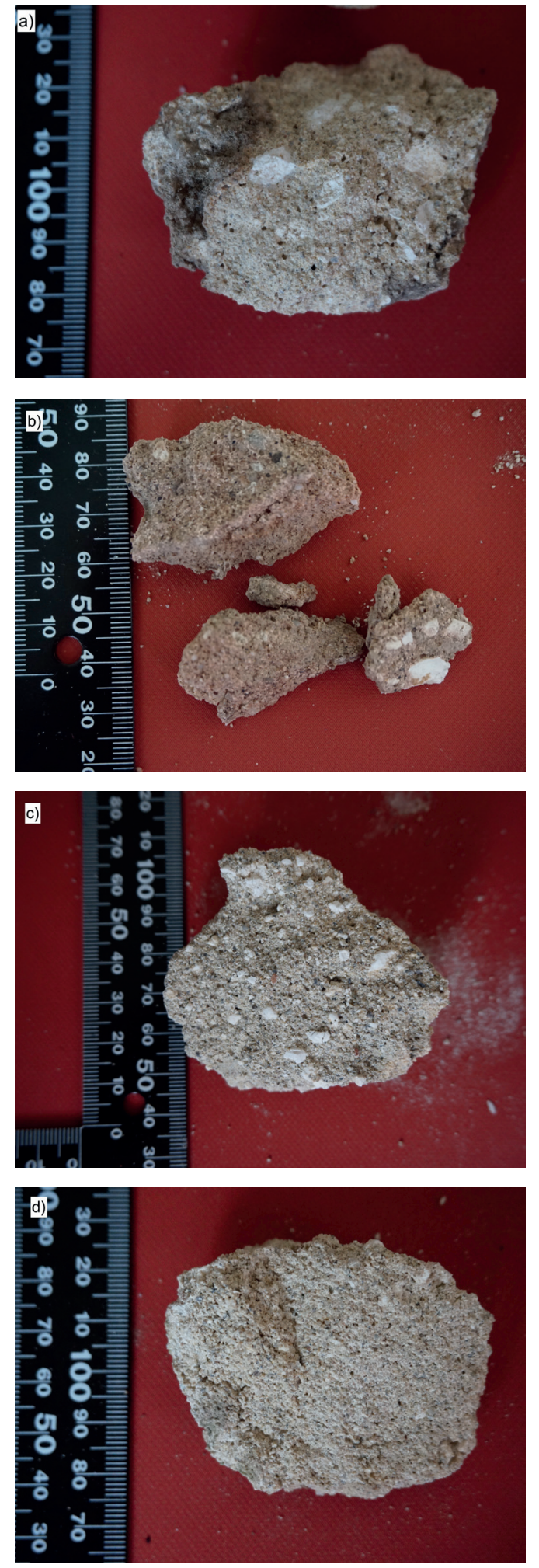

Fig. 6 Original medieval mortar samples: (a) 1-02 sample of yellowish lime with large sand particles and remains of lime and dolomite grains; (b) 6-02 sample is a pink coloured mortar with crushed red bricks and remains of large lime and dolomite practices; (c) 7-02 sample yellow lime mortar with large sand particles and higher lime and dolomite grain content than sample 1-02; (d) 13-01 sample: yellow lime mortar with evident sand particles, and more homogenous composition
Table 1 Description of lime mortars based on macroscopic observation (sample codes and locations are also provided)

\begin{tabular}{|c|c|c|}
\hline Sample & Masonry site & Macroscopic features \\
\hline $1-02$ & $\begin{array}{l}\text { Northern wall, } \\
\text { outside }\end{array}$ & $\begin{array}{l}\text { Slightly yellowish lime mortar with } \\
\text { large sand particles and remains of large } \\
\text { lime and dolomite particles. }\end{array}$ \\
\hline 6-02 & $\begin{array}{l}\text { Sanctuary } \\
\text { southern wall, } \\
\text { outside }\end{array}$ & $\begin{array}{l}\text { Joint containing crushed red bricks. } \\
\text { Pink coloured lime-based mortar with } \\
\text { large lime and dolomite particles. }\end{array}$ \\
\hline 7-02 & $\begin{array}{l}\text { Southern wall, } \\
\text { outside }\end{array}$ & $\begin{array}{c}\text { Slightly yellowish lime mortar with } \\
\text { large sand particles and a significant } \\
\text { amount of large lime and dolomite } \\
\text { particles. }\end{array}$ \\
\hline $13-01$ & $\begin{array}{l}\text { Sanctuary } \\
\text { north part, } \\
\text { inside }\end{array}$ & $\begin{array}{l}\text { Slightly yellowish lime mortar with } \\
\text { large sand particles and remains of } \\
\text { small lime and dolomite particles. }\end{array}$ \\
\hline
\end{tabular}

walls. They have relatively low percentages of structurally bound water and high carbon dioxide content, with relatively lower strength [15].

The latest (modern) mortars were used less extensively at the ruins. This grey newly applied renders are very distinct from historic lime mortars, because of the presence of high Portland cement content. The Portland cement gives light to dark grey colour to these renders. The grey cementitious mortars are less porous than the lime mortars (Fig. 7).
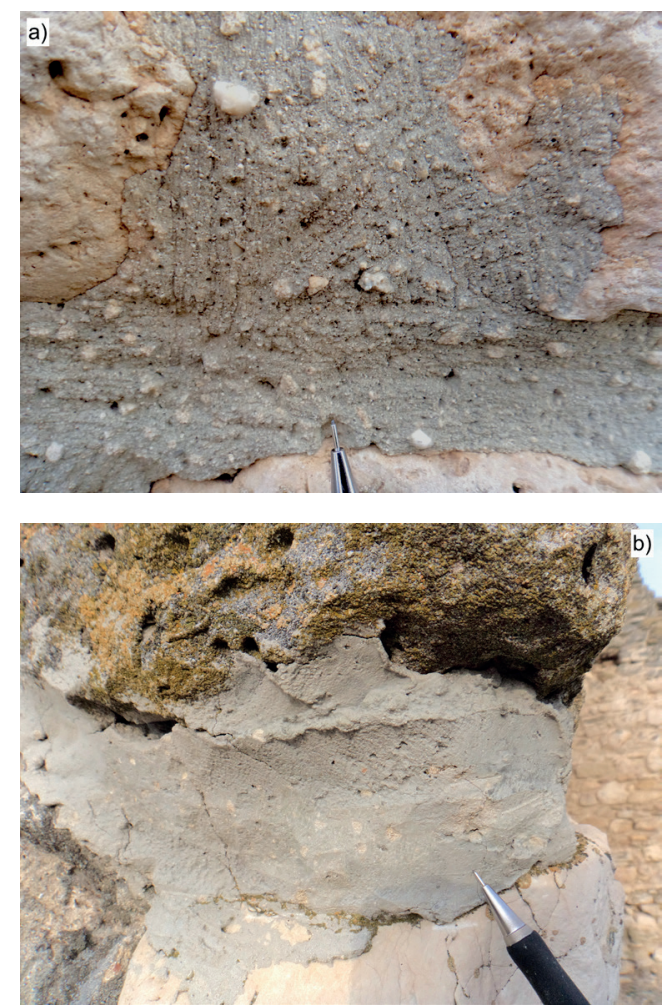

Fig 7 Examples of modern binders: (a) PC-1: Dark grey binder containing high amount of Portland cement, with white lime grains and black sand grains; (b) PC-2: Light grey plaster containing high amount of Portland cement, with very fine grinded sand 
This is due to the fact that cement-based binder was used as repair mortar in the time of reconstruction, in 2000. At this time, the ruin was excavated and parts of the walls were restored.

\section{Weathering forms}

Several types of weathering forms were observed on the different parts of the masonry.

The most common weathering forms are selective dissolution that is observed at limestone ashlar (Fig. 8(a-b)). Weathering crust formation is common not only on limestone but also on fine-grained sandstone masonry elements. The multiple flaking of these crusts is a common decay form (Fig. 8. (c-d)).

Biological weathering appears on all lithotypes. Light grey lichens and green lichens with the colonisation of green algae are also common (Fig. 9). The latter ones mainly occur on wet zones of the ruin.

Weathering process can cause rapid changes in stone heritage, and the visible sign can appear in years [16]. Thus at this Medieval ruin, the last centuries can cause major changes, and weathering forms could be developed during that period.
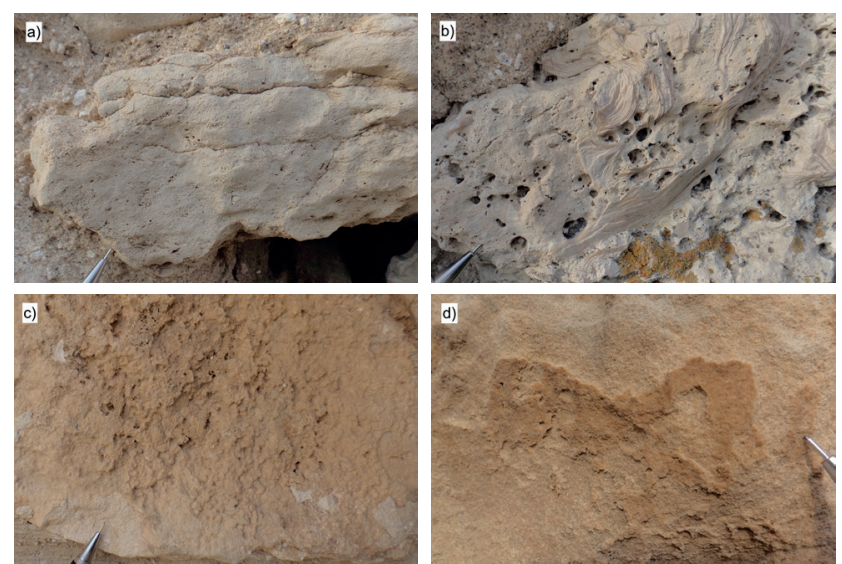

Fig. 8 Weathering forms at the inner parts of the ruin: (a) and (b) selective dissolution; (c) and (d) multiple flacking on sandstone surface
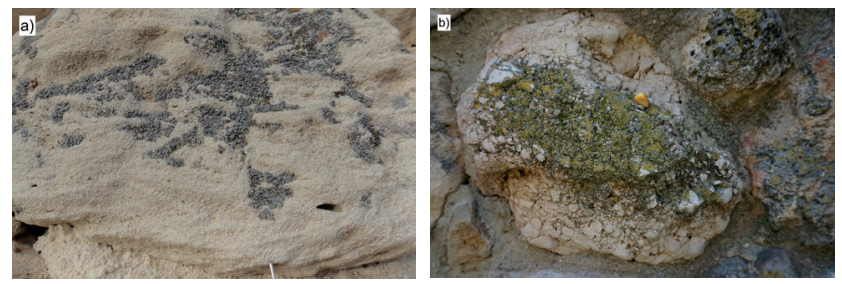

Fig. 9 Biological weathering forms: lichens colonized the stone surfaces: (a) grey liches on limestone (b) dolomite-breccia with light green lichen layer

\section{Non-destructive surface strength - Schmidt hammer}

Schmidt hammer was used to test the surface strength of stone. The readings of the rebound values can be converted to compressive strengths or other parameters [17]. At the ruin of Tök an N-34 type of Schmidt hammer has been applied on each lithotypes of stone elements of the masonry (Fig. 10). At each tested element, at least ten tests were made and the mean values and standard deviations of the readings were calculated. The different types of stone surfaces, at where tests were made, are shown in Fig. 5.

The values of the Schmidt hammer test helped in distinguishing the different lithotypes by surface hardness. The highest rebound values characterized the slightly cracked surfaced Triassic limestone (see Fig. 5(c)) and the second highest rebound values were detected on limestones with high sand content (Fig. 11). Low values characterize most types of porous limestones and porous new replacement limestones (see Fig 5(e-f)). The replacement stones generally have the lowest rebound values (Fig. 11).

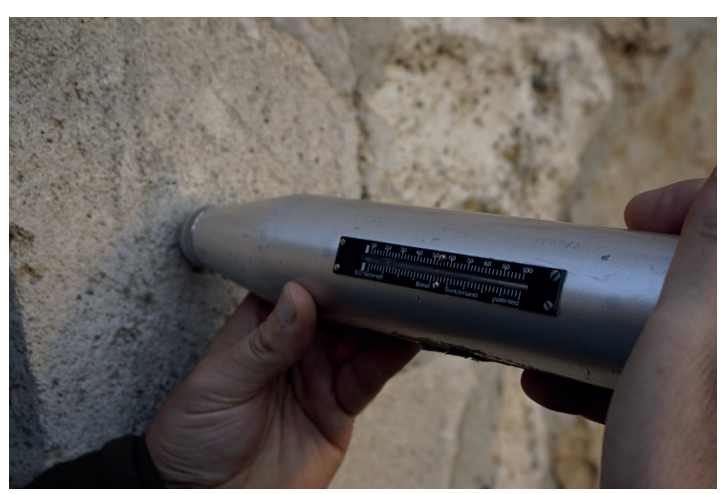

Fig. 10 Surface testing with Schmidt hammer

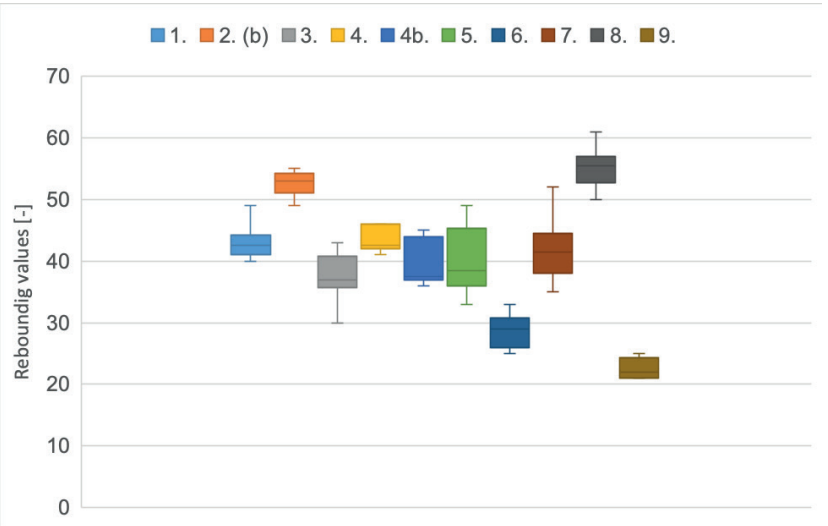

Fig. 11 Schmidt hammer rebound values on different lithotypes: 1 . highly cemented limestone; 2 .b porous limestone with fine sand; 3 . porous sandy limestone with shells; 4 . sandstone; 4 .b coarse sandstone; 5. porous limestone with small pebbles and shells; 6. ooidal limestone; 7. cross-layered porous limestone; 8 . Triassic, cross-layered limestone; 9. ooidal limestone (replacement blocks) 


\section{Relative moisture content of surfaces}

The moisture content of masonry materials is an important factor that influences the long-term behaviour of stones and binders $[18,19]$. To analyse the relative moisture content of construction materials (stones and mortars), a Gann-Hydromette Uni, a portable moisture content testing device was used (Fig. 12). This portable device does not provide absolute values (percentage) of moisture content, but the obtained numerical values can be used in comparison with other measuring points. A profile of relative moisture content also provides information on the differences between materials. The relative moisture content of stone elements and binders have been measured on four sections of the walls, and more than 100 points were recorded at each section.

The average values of relative moisture content were high both at the external (Fig. 13) and at the internal side (Fig. 14) of the sanctuary.

These high values were expected due to the unsheltered condition. However, we could observe a clear difference between values of lime mortar, and Portland cement-based repair renders, and there was a difference of moisture content of various lithotypes, too.

The scatter of the moisture content is much higher at the internal part of the sanctuary (Fig. 13) than at the external part (Fig. 14). Micro-climatic conditions control these differences, namely exposure to wind or rain influences moisture content. In previous studies, it has been demonstrated that moisture content influences the behaviour of stone and render [19]. The pore structure also influences the water absorption and thus the frost resistance of the stone [20]. The differences in the porosity of stone and mortar, the compatibility [5] might lead to differential weathering and loss of stone material. The different moisture content

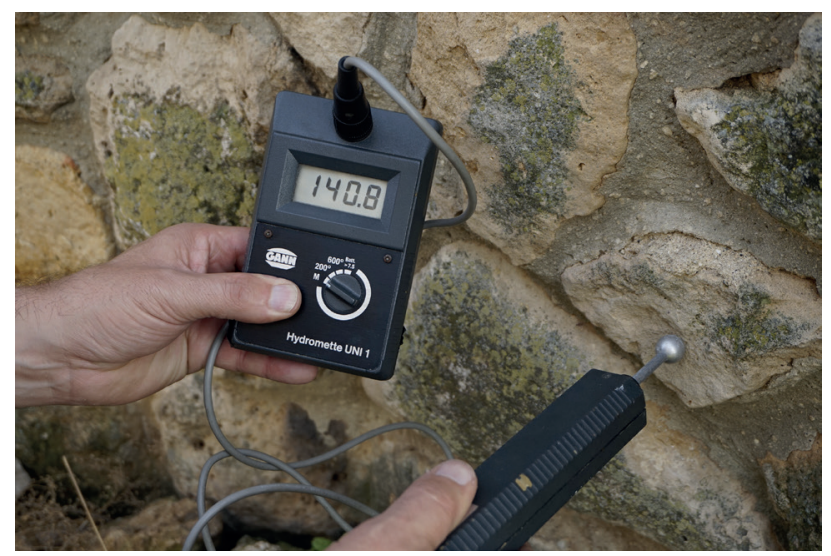

Fig. 12 Estimation of the structural moisture content with GannHydromette Uni device

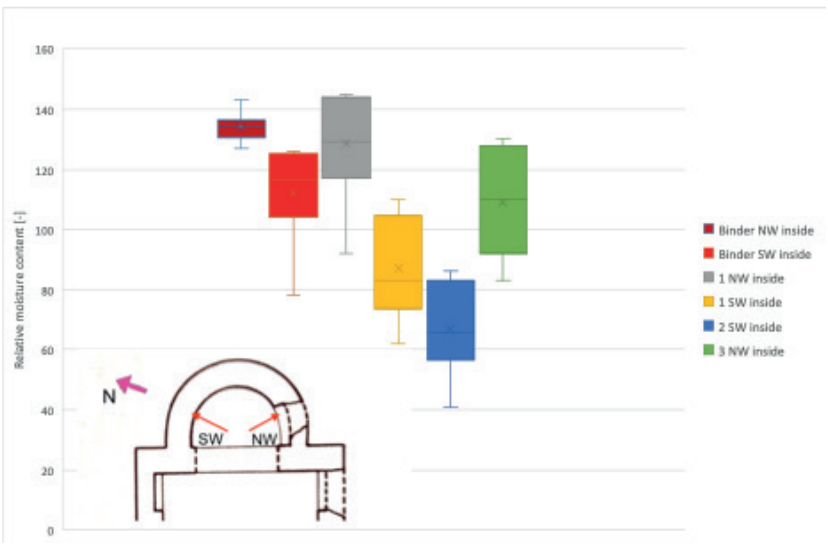

Fig. 13 The relative moisture content of different lithotypes and binders at the internal side of the sanctuary: binder highly cemented limestone (1); 2.b and porous limestone with fine-grained sand (2) and porous sandy limestone with shells (3)

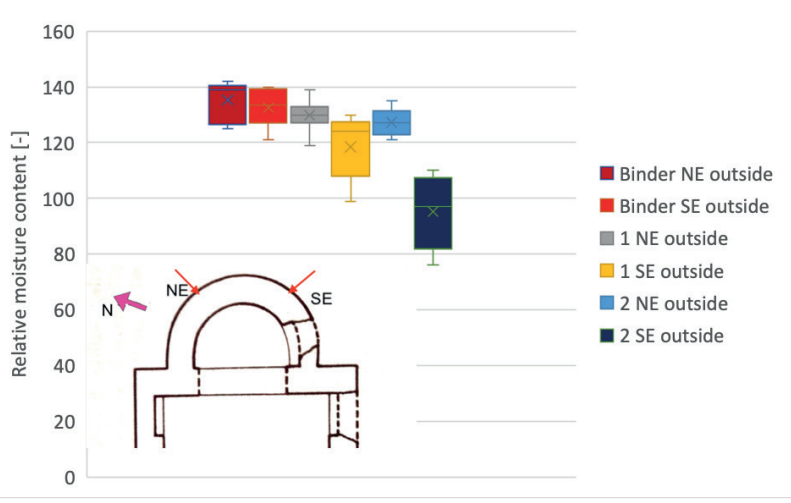

Fig. 14 The relative moisture content of different lithotypes and binders at the external side of the sanctuary: binder; highly cemented limestone

(1); porous limestone with fine-grained sand (2)

of different lithotypes suggests that the porosity and poresize distribution of various limestone types are different, and thus their resistance against freeze-thaw related weathering is also different.

\section{Microscopic analyses}

Thin section examination suggests that binder structure and composition are complex and that binder quantity can vary significantly during the lifetime of a mortar [21].

To prepare thin sections of mortar material, it is usually necessary to impregnate the often-brittle samples [22]. Our thin sections were prepared by using epoxy resin, the average thickness of thin sections was $30 \mu \mathrm{m}$.

As it is visible under the microscope, the historic mortar is composed of small angular quartz grains and larger sand-sized lithic clast (Fig. 15). The binder of this mortar is lime. There are calcareous lumps that mark the improper preparation technique (Fig. 16) [23]. 
The lime-based mortars are generally resistant to weathering [4], but at highly exposed conditions, they can decay.

The microscopic analyses indicated that the micro-fabric of mortars are different from the porous limestone. In the latter one carbonate grains prevail (mostly ooids see Fig. 17), while in medieval lime-based mortars quartz grains dominate. These differences can also contribute to the differences in durability $[1,5]$.

The microscopic characters of the limestone lithotypes are also very different. In the oolitic limestone intergranular pores are common. While at bioclastic limestone
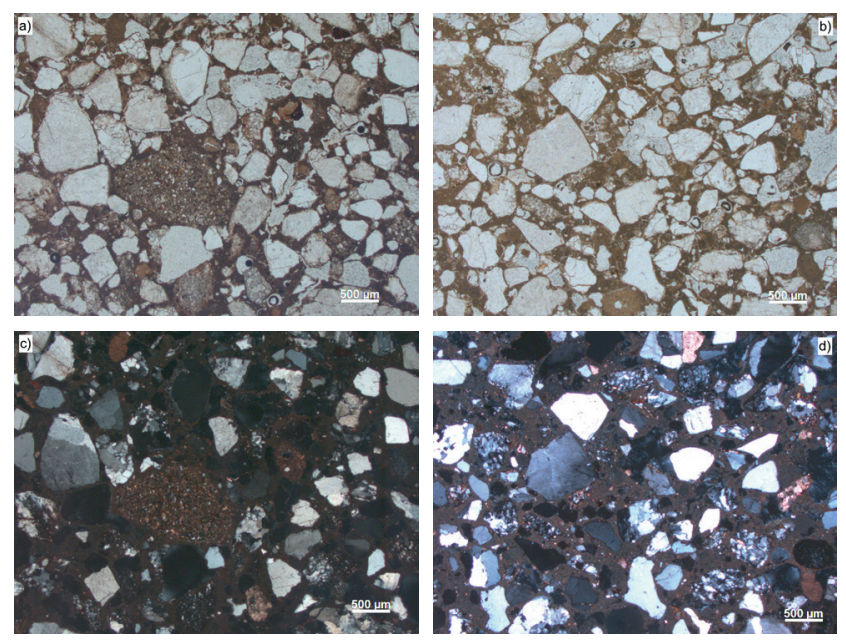

Fig. 15 (a-b) Thin section images of lime binders from investigation point 6-02-A. Coarse grains as aggregate particles appear white and the matrix appears dark red, (c-d) same thin section images but seen under crossed-polarized light, showing quartz sand (grey/white), and basalt fine aggregate particles and carbonated nonhydraulic lime binder (brown)

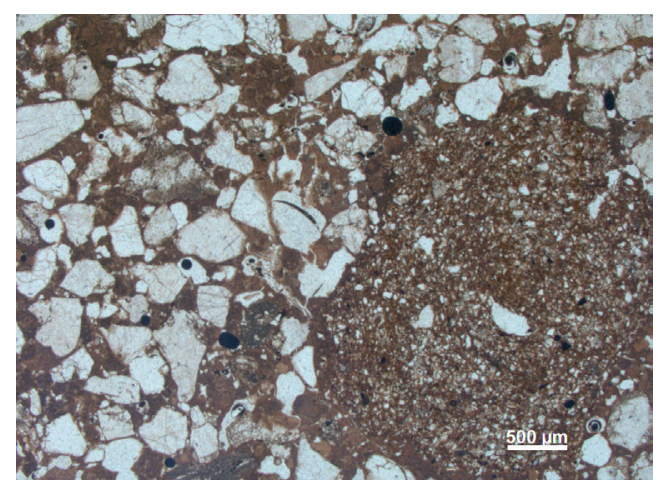

Fig. 16 Thin section image of lime binders from (sample 1-02). Coarse grains as aggregate particles appear white and the matrix appears dark

\section{References}

[1] Isebaert, A., Van Parys, L., Cnudde, V. "Composition and compatibility requirements of mineral repair mortars for stone - A review", Construction and Building Materials, (59), pp. 39-50, 2014. https://doi.org/10.1016/j.conbuildmat.2014.02.020
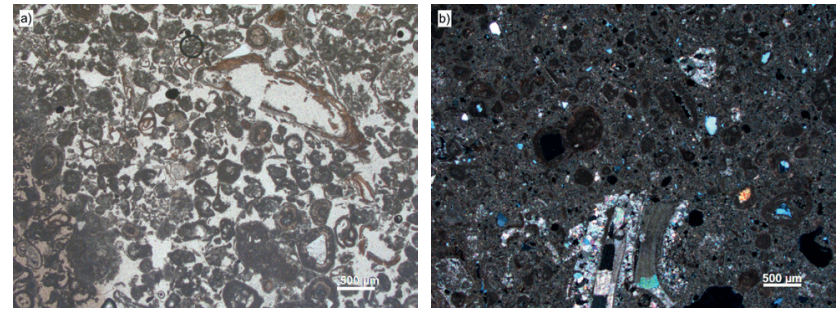

Fig. 17 Microscopic images of (a) ooidal limestone that contains larger bioclasts and (b) a shelly oolitic limestone with coated quartz grains

the intraparticle and mouldic pores are also present. The smaller pores are more prone to frost damage and this lithotypes might have lower strength [24]. It has been outlined that the porosity and pore structure of limestone are good indicators of their durability [20,25]. The oolitic limestone lithotype is prone to freeze-thaw damage and also to thermal degradation [26].

\section{Conclusions}

When conserving and restoring historic buildings, it is often necessary to find the appropriate methods to analyse the structures and building materials and test results and experiments can support to choose the adequate building materials during the planning of restoration works.

This study initiated from the lack of documents and information on medieval ruins of Hungary. To reconstruct the church, it was necessary to take digital images and make a 3D model of the site. In the next step, material identification and testing help to outline the different construction periods. With the combination of these methods, it was possible to get information on medieval architecture. The applied techniques can help to plan the future reconstruction and management of other ruined sites, in the form of material selection, architectural design, and preservation plans. In the future, the establishment of a database of medieval ruins of Hungary is planned. It would provide a solid background for various reconstructions and possible utilization of the ruins.

\section{Acknowledgement}

The authors would like to acknowledge financial support from the European Committee through the National Research, Development and Innovation Office (Project NKFI/M-ERA.NET2/127023).

[2] Jokilehto, J. "A History of Architectural Conservation", Elsevier, Oxford, UK, 1999.

[3] Prrikryl, R. "Durability assessment of natural stone", Quarterly Journal of Engineering Geology and Hydrogeology, (46), pp. 377390, 2013.

https://doi.org/10.1144/qjegh2012-052 
[4] Papayianni, I. "The longevity of old mortars", Applied Physics A, (83), pp. 685-688, 2006.

[5] Török, Á., Szemerey-Kiss, B. "Freeze-thaw durability of repair mortars and porous limestone: compatibility issues", Progress in Earth and Planetary Science, (6), Article number: 42, 2019. https://doi.org/10.1186/s40645-019-0282-1

[6] Snow, J., Torney, C. "Lime Mortars in Traditional Buildings: Short Guide 6", Historic Scotland, Edinburgh, Scotland, 2014. [online] Available at: https://www.historicenvironment.scot/archives-andresearch/publications/publication/?publicationId $=85$ ced9f0-474d4ec6-8dd6-a59100fc306f [Accessed: 10 December 2019]

[7] Faria, P., Henriques, F., Rato, V. "Comparative evaluation of lime mortars for architectural conservation", Journal of Cultural Heritage, 9(3), pp. 338-346, 2008.

https://doi.org/10.1016/j.culher.2008.03.003

[8] Cardini, G., Binda, L. "Guidelines for the Evaluation of the LoadBearing Masonry Quality in Built Heritage", In: Toniolo, L., Boriani, M., Guidi, G. (eds.) Built Heritage: Monitoring Conservation management, Springer, Cham, Swizerland, 2015, pp. 127-139. https://doi.org/10.1007/978-3-319-08533-3_11

[9] Tari, E. "Pest megye középkori templomai" (Medieval Churches in Pest County), Studia Comitatensia, 27, Szentendre, Hungary, 2000. (in Hungarian)

[10] Mentényi, F. K. (ed.) "Müemlékvédelmi Szemle 1999/1-2", Országos Mủemlékvédelmi Hivatal, Budapest, Hungary, 1999.

[11] Dinnyés, I., Kővári, K., Lovag, Zs., Tettamanti, S., Topál, J., Torma, I. "Tök" (Tök village) In: Magyarország Régészeti Topográfiája 7. A budai és szentendrei járás (Archeological topography of Hungary 7.) Akadémiai Kiadó, Budapest, Hungary, 1986, pp. 336-342. (in Hungarian)

[12] Haas, J. (ed.) "Geology of Hungary", Springer, Berlin, Heidelberg, Germany, 2012. https://doi.org/10.1007/978-3-642-21910-8

[13] Török, Á., Müller, C., Hüpers, A., Hoppert, M., Siegesmund, S., Weiss, T. "Differences in texture, physical properties and microbiology of weathering crust and host rock: a case study of the porous limestone of Budapest (Hungary)", In: Prykril, R., Smith, J. B. (eds.) Building Stone Decay: From Diagnosis to Conservation, Geological Society, London, UK, 2007, pp. 261-276. https://doi.org/10.1144/GSL.SP.2007.271.01.25

[14] Balksten, K. "Understanding historic mortar and their variations a condition for performing restorations with traditional materials", In: Proceedings of 2nd Historic Mortars Conference and RILEM TC 203-RHM Final Workshop, Prague, Czech Republic, 2010, pp. 11-18. [online] Available at: http://www.ancientportsantiques.com/ wp-content/uploads/Documents/ETUDESarchivees/Maçonnerie/ BétonRomain/Historic\%20Mortars-HMC2010.pdf [Accessed: 10 December 2019]

[15] Moropoulou, A., Bakolas, A., Anagnostopoulou, S. "Composite materials in ancient structures", Cement and Concrete Composites, 27(2), pp. 295-300, 2005.

https://doi.org/10.1016/j.cemconcomp.2004.02.018
[16] Gomez-Heras, M., McCabe, S. "Weathering of stone-built heritage: A lens through which to read the Anthropocene", Anthropocene, (11), pp. 1-13, 2015. https://doi.org/10.1016/j.ancene.2015.12.003

[17] Török, Á. "Schmidt hammer and duroscope tests in assessing surface properties of stones", In: In situ monitoring of monumental surfaces, Proceedings of the International Workshop SMW08, Florence, Italy, 2008, pp. 207-214.

[18] Török, Á. "In Situ Methods of Testing Stone Monuments and the Application of Non-destructive Physical Properties Testing in Masonry Diagnosis", In: Bostenaru Dan, M., Přikryl, R., Török, Á. (eds.) Materials, Technologies and Practice in Historic Heritage Structures, Springer, Dordrecht, Netherlands, 2010, pp. 177-193. https://doi.org/10.1007/978-90-481-2684-2_10

[19] Martínez-Garrido, M. I., Fort, R., Gómez-Heras. M, Valles-Iriso, J., Varas-Muriel, M. J. "A comprehensive study for moisture control in cultural heritage using non-destructive techniques", Journal of Applied Geophysics, (155), pp. 36-52, 2018. https://doi.org/10.1016/j.jappgeo.2018.03.008

[20] Benavente, D., García del Cura, M. A., Fort, R., Ordóñez, S. "Durability estimation of porous building stones from pore structure and strength", Engineering Geology, 74(1-2), pp. 113-127, 2004. https://doi.org/10.1016/j.enggeo.2004.03.005

[21] Leslie, A. B., Hughes, J. J. "Binder microstructure in lime mortars: analysis results", Quarterly Journal of Engineering Geology and Hydrogeology, 35, pp. 257-263, 2002. https://doi.org/10.1144/1470-923601-27

[22] Blaeuer, C., Kueng, A. "Examples of microscopic analysis of historic mortars by means of polarising light microscopy of dispersions and thin sections", Materials Characterization, 58(11-12), pp. 11991207, 2007. https://doi.org/10.1016/j.matchar.2007.04.023

[23] Ingham, J. P. "Mortar, plaster and render", In: Geomaterials Under the Microscope, Manson Publishing Ltd., London, UK, 2013, pp. 137-162. https://doi.org/10.1016/B978-0-12-407230-5.50016-9

[24] Pappalardo, G., Mineo, S., Monaco, C. "Geotechnical characterization of limestones employed for the reconstruction of a UNESCO world heritage Baroque monument in southeastern Sicily (Italy)", Engineering Geology, 212, pp. 86-97, 2016. https://doi.org/10.1016/j.enggeo.2016.08.004

[25] Alves, C., Figueiredo, C., Sanjurjo-Sánchez, J. "Rock Features and Alteration of Stone Materials Used for the Built Environment: A Review of Recent Publications on Ageing Tests", Geosciences, 10(3), Article number: 91, 2020. https://doi.org/10.3390/geosciences10030091

[26] Pápay, Z., Török, Á. "Effect of Thermal and Freeze-thaw stress on the Mechanical Properties of Porous Limestone", Periodica Polytechnica Civil Engineering, 62(2), pp. 423-428, 2018. https://doi.org/10.3311/PPci.11100 